\title{
Physiological potential of piquin pepper seeds in response to pregermination treatments
}

\section{Potencial fisiológico de sementes de pimenta "piquin" em resposta a tratamentos pré-germinativos}

\author{
Miguel Ángel Cano-González ${ }^{1}$ (D), Benjamín Abraham Ayil-Gutiérrez² (D), Rafael Delgado-Martínez (D), \\ Eduardo Osorio-Hernández ${ }^{1}$ (D) , José Antonio Rangel-Lucio ${ }^{3}$ (D) Wilberth Alfredo Poot-Poot ${ }^{1 *}$ (iD)
}

\author{
`Universidad Autónoma de Tamaulipas, Facultad de Ingeniería y Ciencias, Cd. Victoria, Tamaulipas, Mexico \\ IInstituto Politécnico Nacional, CONACYT- Centro de Biotecnología Genómica, Reynosa, Tamaulipas, Mexico \\ IInstituto Tecnológico de Ciudad Victoria, Cd. Victoria, Tamaulipas, Mexico \\ ${ }^{*}$ Corresponding author: wpoot@docentes.uat.edu.mx \\ Received September 6, 2021 and approved November 5, 2021
}

\section{ABSTRACT}

Wild piquin pepper fruits are consumed and traded because of their flavor, nutritional and pharmaceutical properties. The heterogeneous germination of its seeds has caused pregermination treatments to be unstandardized. Because of that, our goal was to evaluate pregermination treatments of piquin pepper seeds from a wild plant from the municipality of Victoria, Tamaulipas, Mexico, consisting of immersion for different periods $(2,24,48 \mathrm{~h})$ in solutions with variable concentrations of the growth regulators naphthalene acetic acid (NAA; 0.1, 1.0, $2.5 \mathrm{mM}$ ), salicylic acid (SA; 1.0, 5.0, $10 \mathrm{mM})$, gibberellic acid $\left(\mathrm{GA}_{3}, 1.0,5.0,10 \mathrm{mM}\right)$, indole-3butyric acid (IBA; 1.0, 2.0, $3.0 \mathrm{mM}$ ), the commercial product Biozyme (Bioz) containing minerals and growth regulators (Bioz; 0.5, 1 , $2 \%)$, and sulfuric acid $\left(\mathrm{H}_{2} \mathrm{SO}_{4} ; 2,5,10 \%\right)$ in a completely randomized design, using distilled water as the control. For each treatment, we measured the imbibition ratio, germination percentage, time to obtain $50 \%$ germination $\left(T_{50}\right)$, and coefficient of variation of germination time $(\mathrm{CVt})$. Our results showed that the imbibition was similar in the control and the treatments, but it differed between treatments. The highest imbibition recorded in $48 \mathrm{~h}$ was $87 \%$. The highest germination percentage (79.2\%) was achieved with $2 \mathrm{~h}$ immersion in 2\% Bioz, followed by $1 \mathrm{mM} \mathrm{NAA} \mathrm{(62 \% )} \mathrm{and} 5 \mathrm{mM} \mathrm{SA}(56 \%)$. $\mathrm{T}_{50}$ and CVt were 10-26 d and 0-39\%, respectively. According to our results, we concluded that the pregermination treatments we assayed improved the physiological potential for the germination of piquin pepper seeds.
\end{abstract}

Index terms: Capsicum annuum L. var. glabriusculum (Dunal) Heiser \& Pickershill; growth regulators; imbibition; germination.

\begin{abstract}
RESUMO
Os frutos silvestres da pimenta piquín são consumidos e comercializados, devido ao seu sabor e propriedades nutracêuticas. a germinação heterogênea das sementes fez com que os tratamentos pré-germinativos não fossem padronizados. Portanto, nosso objetivo foi avaliar tratamentos pré-germinativos de sementes de pimenta piquín de uma planta silvestre do município de Victoria, Tamaulipas, México, consistindo em imersão por diferentes períodos (2, 24 e 48 h) em soluções com concentrações variáveis dos seguintes hormônios vegetais: ácido naftaleno acético (NAA; 0,1, 1,0, 2,5 mM), ácido salicílico (SA; 1,0, 5,0, $10 \mathrm{mM}$ ), ácido giberélico (GA3, 1,0, 5, 0,10 mM), ácido indol-3-butírico (IBA; 1,0, 2,0, 3,0 mM), além do bioestimulante comercial Biozyme comercial (Bioz) contendo minerais e reguladores de crescimento (Bioz; $0,5,1,2 \%)$ e ácido sulfúrico $\left(\mathrm{H}_{2} \mathrm{SO}_{4} ; 2,5,10 \%\right)$ em um delineamento inteiramente casualizado. usando água destilada como controle. Para cada tratamento, medimos o índice de embebição, a porcentagem de germinação, o tempo para obtenção de 50\% de germinação (T50) e o coeficiente de variação do tempo de germinação (CVt). Nossos resultados mostraram que a embebição foi semelhante no controle e nos tratamentos, mas diferiu entre os tratamentos. A maior embebição registrada em $48 \mathrm{~h}$ foi de $87 \%$. A maior porcentagem de germinação (79,2\%) foi alcançada com $2 \mathrm{~h}$ de imersão em $2 \%$ Bioz, seguido por 1 mM NAA (62\%) e 5 mM SA. T50 e CVt foram de 10-26 dias e 0-39\%, respectivamente. De acordo com nossos resultados, concluímos que os tratamentos de pré-germinação que testamos melhoraram o potencial fisiológico para germinação de sementes de pimenta piquin.
\end{abstract}

Termos para indexação: Capsicum annuum L. var. glabriusculum; regulador vegetal; embebição; germinação. 


\section{INTRODUCTION}

Capsicum annuum L. var. glabriusculum (Dunal) Heiser and Pickershill (piquin pepper) is a perennial plant in the Solanaceae family distributed from the southwestern U.S.A. to Colombia, which is considered to be the ancestor of all cultivated variants of chili peppers belonging to C. annuum (Hayano-Kanashiro; Gámez-Meza; MedinaJuárez, 2016). In their natural environment, wild piquin pepper plants associate with trees or shrubs that provide them shade, phytosanitary protection, and soil organic matter. In Mexico, local people harvest fruits from wild populations and cultivate plants for consumption and sale. Because of genetic resistance to the diseases and environmental stress factors present in their populations, piquin pepper has the potential for the genetic improvement of cultivated chilli peppers (Lin et al., 2021).

The fruits of the piquin pepper are consumed fresh (with a green pericarp), dried (red), and in processed products due to their organoleptic properties (pungency, taste, and smell) and low irritability to the digestive tract. Piquin pepper fruits also have phytochemical molecules with nutritional and pharmaceutical attributes, including phenolic compounds, capsaicinoids, carotenoids, and tocopherols of health importance (Hayano-Kanashiro; Gámez-Meza; Medina-Juárez, 2016; Treto-Alemán et al., 2021). The sale of fruits, gathered from wild plants or harvested from cultivated plants during the rainy season, contributes to the economy of rural populations, and their market value is up to 40 times that of the jalapeño or serrano varieties (Villalon-Mendoza et al., 2014). However, the harvesting methods applied cause mechanical damage to the plants, and in extreme cases, their removal, which compromises their regeneration, lowers their productivity and decreases the population's genetic diversity (Medina-Martínez et al., 2010).

The germination rate of wild piquin pepper seeds is under $20 \%$, which limits their domestication and commercialization as a crop (López-España et al., 2017; Quintero et al., 2018). This low germination rate is due to a variable degree of seed dormancy, which can be caused by several factors, including the mucilaginous cover in the seed coat (testa), which hardens when dry, a high concentration of germination-inhibiting compounds such as abscisic acid (ABA) or capsaicin, and rudimentary or physiologically immature embryos (Prado-Urbina et al., 2015; Barchenger; Bosland, 2016; Mares-Quiñones; Valiente-Banuet, 2019). Additionally, Herrera-Aguilar et al. (2018) reported a loss of viability after seeds were subjected to accelerated aging.
The proposed pregermination treatments for overcoming dormancy in Capsicum spp. seeds and making their germination response uniform include physical (hydrothermal, light) and chemical $\left(\mathrm{KNO}_{3}\right.$, strong acids such as $\mathrm{H}_{2} \mathrm{SO}_{4}$ and $\mathrm{HNO}_{3}$, and growth regulators) agents or their combination. For treatment with growth regulators, seeds are imbibed by immersion in chemical solutions for a period of time, which triggers the activation of enzymes and growth regulators, starch hydrolysis, and nutrient transport favoring embryo growth and development (Louf et al., 2018). Growth regulators used for pregermination treatments include $5.70 \mathrm{mM}$ indoleacetic acid (IAA), $0.04-0.4 \mathrm{mM}$ kinetin, and $0.02-0.2 \mathrm{mM}$ gibberellic acid $\left(\mathrm{GA}_{3}\right)$ (Watkins; Cantliffe, 1983). However, Mireles-Rodríguez et al. (2015) reported a variable germination response of piquin pepper seeds depending on their provenance in the state of Tamaulipas, Mexico: seeds collected in Ocampo and Jaumave had a better germinative and agronomic performance after treatment with $14.4 \mathrm{mM} \mathrm{GA}_{3}$ than those collected in Chamal and San Carlos.

The genetic variability present in the wild populations of piquin pepper, expressed in the morphological characteristics of plants and fruits, has hampered the finding of a general pregermination treatment protocol. Despite the advancements made in the knowledge about the germination of chili pepper seeds, the imbibition behavior of seeds in conditioning solutions, the distribution of solutes in their tissues, and the response and action mechanisms of plant growth hormones remain unclear (Terskikh et al., 2011; Silva et al., 2020). For that reason, our objective in this study was to evaluate the effect of pregermination treatments based on growth regulators, sulfuric acid, and Biozyme solutions at different immersion periods on the imbibition and germination of piquin pepper seeds.

\section{MATERIAL AND METHODS}

\section{Location of the experiment}

The assays were carried out in the Plant Biotechnology Laboratory of the Engineering and Sciences Faculty of the Autonomous University of Tamaulipas in Ciudad Victoria, Tamaulipas, Mexico.

\section{Processing of fruits and seed selection}

Fruits were collected from a wild plant growing in a rural area in the community of Tierra Nueva 
$\left(23^{\circ} 50^{\prime} 28^{\prime \prime} \mathrm{N}, 99^{\circ} 7^{\prime} 39^{\prime \prime} \mathrm{W}\right)$ in the municipality of Victoria, Tamaulipas. Mature fruits (selected for their red color) were picked and washed in $1 \%$ commercial dish detergent (Axion, Colgate-Palmolive Company) for $10 \mathrm{~min}$, had their pericarp removed with a plastic spatula, and then were rinsed in sterile water to eliminate the remaining mucilage. The seeds that floated in the rinsing water were removed. The selected seeds were air dried at room temperature and stored for 30 days in Petri dishes at $25{ }^{\circ} \mathrm{C}$ and $50 \%$ relative humidity.

\section{Pregermination treatment solutions}

Pregermination imbibition solutions contained distilled water as the control treatment; $0.1,1.0$, and 2.5 mM NAA (Sigma-Aldrich); 1.0, 5.0, and $10 \mathrm{mM} \mathrm{SA}$ (Wako 196-14861); 1.0, 5.0, and $10 \mathrm{mM} \mathrm{GA}_{3}$ (Biogib 10ps, GBM S.A. de C.V.); 1.0, 2.0, and 3.0 mM IBA (Bio Basic IB0725); 0.5, 1, and 2\% Bioz (GBM S.A. de C.V.); and 2, 5, 10\% sulfuric acid $\left(\mathrm{H}_{2} \mathrm{SO}_{4}\right.$; Jalmek Científica
S.A. de C.V.). The combination of products and their concentrations defined the treatments (Table 1).

\section{Imbibition and germination assays}

For the imbibition assays, the dry weight of the seeds was measured in an analytical balance (Nimbus 254e, Adam NBL), after which the seeds were placed in Petri dishes containing the treatment solutions and imbibed for 2, 24, and $48 \mathrm{~h}$. Each treatment used 25 seeds in triplicate. The Petri dishes were placed in a culture room at $25^{\circ} \mathrm{C}$ and a $16 / 8 \mathrm{~h}$ (light/darkness) photoperiod. After the imbibition period, the seeds were carefully removed from Petri dishes with tweezers, placed on paper towels to remove the excess solution, and weighed. Immediately after, they were reimmersed in the corresponding treatment solution.

The seeds used for germination assays were first disinfected by soaking them for $10 \mathrm{~min}$ in $70 \%(\mathrm{v} / \mathrm{v})$ ethanol, rinsing them twice in distilled water for 10 min each time, soaking them in $10 \%(\mathrm{v} / \mathrm{v})$ commercial

Table 1: Pregermination treatments applied to piquin pepper seeds.

\begin{tabular}{cccccccc}
\hline $\begin{array}{c}\text { Treatment } \\
\text { number }\end{array}$ & $\begin{array}{c}{\left[\text { dist. } \mathrm{H}_{2} 0\right]} \\
(\%) \mathrm{Ctrl}\end{array}$ & $\begin{array}{c}{[\mathrm{NAA}]} \\
(\mathrm{mM})\end{array}$ & $\begin{array}{c}{[\mathrm{SA}]} \\
(\mathrm{mM})\end{array}$ & $\begin{array}{c}{\left[\mathrm{GA}_{3}\right]} \\
(\mathrm{mM})\end{array}$ & $\begin{array}{c}{[\mathrm{IBA}]} \\
(\mathrm{mM})\end{array}$ & $\begin{array}{c}{[\mathrm{Bioz}]} \\
(\%)\end{array}$ & $\begin{array}{c}{\left[\mathrm{H}_{2} \mathrm{SO}_{4}\right]} \\
(\%)\end{array}$ \\
\hline 1 & 100 & - & - & - & - & - & - \\
2 & - & 0.1 & - & - & - & - & - \\
3 & - & 1.0 & - & - & - & - & - \\
4 & - & 2.5 & - & - & - & - & - \\
5 & - & - & 1.0 & - & - & - & - \\
6 & - & - & 5.0 & - & - & - & - \\
7 & - & - & 10.0 & - & - & - & - \\
8 & - & - & - & 1.0 & - & - & - \\
9 & - & - & - & 5.0 & - & - & - \\
10 & - & - & - & 10.0 & - & - & - \\
11 & - & - & - & - & 1.0 & - & - \\
12 & - & - & - & - & 2.0 & - & - \\
13 & - & - & - & - & 3.0 & - & - \\
14 & - & - & - & - & - & 0.5 & - \\
15 & - & - & - & - & - & 1.0 & - \\
16 & - & - & - & - & - & 2.0 & - \\
17 & - & - & - & - & - & - & - \\
18 & - & - & - & - & - & - & 2.0 \\
19 & - & - & - & - & - & 10.0
\end{tabular}

Abbreviations: dist. $\mathrm{H}_{2}$ O: Distilled water. Ctrl: Control. NAA: Naphthaleneacetic acid. SA: Salicylic acid. GA ${ }_{3}$ Gibberellic acid. IBA: Indole-3-butyric acid. Bioz: Biozyme. $\mathrm{H}_{2} \mathrm{SO}_{4}$ : Sulfuric acid. 
hypochlorite solution for $10 \mathrm{~min}$, and finally rinsing them twice in distilled water for $10 \mathrm{~min}$ each time. The germination assays were performed in triplicate using 50 disinfected seeds per treatment, and they were placed in Petri dishes containing the respective solution and imbibed for periods of 2, 24, and $48 \mathrm{~h}$. After the imbibition period, the seeds were carefully removed from the Petri dishes with tweezers, rinsed in distilled water to remove the treatment solution, placed in Petri dishes lined with filter paper containing $5 \mathrm{~mL}$ of distilled water, and incubated in a culture room at a temperature of $25^{\circ} \mathrm{C}$ and a $16 / 8 \mathrm{~h}$ (light/darkness) photoperiod for 30 days.

\section{Recorded variables}

\section{Imbibition ratio of seeds}

The amount of water imbibed by the seeds during the treatment period was calculated using the differences between the dry weight $(\mathrm{Wi})$ and the weight of the imbibed seeds after the treatment $(W f)$. For each treatment and immersion period, the imbibition ratio of the seeds was calculated from the total weight gain of the seeds relative to their initial dry weight by the formula:

$W C=\frac{(W f-W i)}{W i} x 100$

where:

$W C=$ seed water content

$W i=$ initial dry weight of seeds

$W f=$ final weight of seeds

\section{Germination percentage}

The percentages of seed germination were obtained by counting the seeds showing radicle emergence every three days for a total of 30 days and then calculating the percentages.

\section{Time to obtain $50 \%$ germination $\left(\mathrm{T}_{50}\right)$}

The time needed to obtain $50 \%$ germination $\left(\mathrm{T}_{50}\right)$ was calculated by the Coolbear, Francis and Grierson (1984) modified by Farooq et al. (2005) equation:

$T_{50}=t_{i}+\frac{\left(\frac{N}{2}-n_{i}\right)\left(t_{j}-t_{i}\right)}{n_{j}-n_{i}}$ where:

$n_{i}=$ number of germinated seeds before reaching $50 \%$ of germinated seeds

$n_{j}=$ number of germinated seeds after reaching $50 \%$ of germinated seeds

$t_{i}=$ time in days before reaching $50 \%$ germinated seeds

$t_{j}=$ time in days after reaching $50 \%$ of germinated seeds

$N=$ total number of germinated seeds

\section{Coefficient of variation of germination time (CVt)}

To obtain information about the variation in germination time in days, the coefficient of variation of germination time $(\mathrm{CVt})$ was calculated following Carvalho, Santana and Ranal (2005) by:

$V t=\frac{S t}{\bar{t}} ; S t=\sqrt{\frac{\sum n_{i}\left(t_{i}-\bar{t}\right)^{2}}{\sum n_{i}-1}} ; \bar{t}=\frac{\sum n_{i} t_{i}}{\sum n_{i}}$

where:

$S t=$ variance of germination time

$\bar{t}=$ mean germination time in days

$n_{i}=$ number of seeds germinated in day $i$

$t_{i}=$ number of days after sowing

\section{Statistical analyses}

The imbibition and germination experiments were performed under a totally randomized experimental model. The germination and imbibition percentages were transformed using the arcsine square root, and the obtained data were statistically analyzed by ANOVA and the Tukey $(p \leq 0.05)$ mean comparison test in Statgraphics Centurion XVI version 16.1.03.

\section{RESULTS AND DISCUSSION}

\section{Seed imbibition}

We observed a gradual increase in the imbibition ratio in response to the applied pregermination treatments relative to the control. At 2, 24, and $48 \mathrm{~h}$, the corresponding germination values were 71,84 , and $87 \%$, respectively. After $2 \mathrm{~h}$ of imbibition, we observed statistically significant differences $(p \leq 0.05)$ within and between the $\mathrm{GA}_{3}(10$ $\mathrm{mM}), \mathrm{NAA}(0.1 \mathrm{mM}), \mathrm{SA}(1 \mathrm{mM}), \mathrm{Bioz}(1 \%)$, and $\mathrm{H}_{2} \mathrm{SO}_{4}$ (5 and 10\%) treatments. The highest percent imbibition $(81.8 \%)$ occurred in the $10 \mathrm{mM} \mathrm{GA}_{3}$ treatment, and the seed imbibition percentages of seeds ranged between 61.1 and $81.8 \%$ (Figure $1 \mathrm{~A}$ ). 

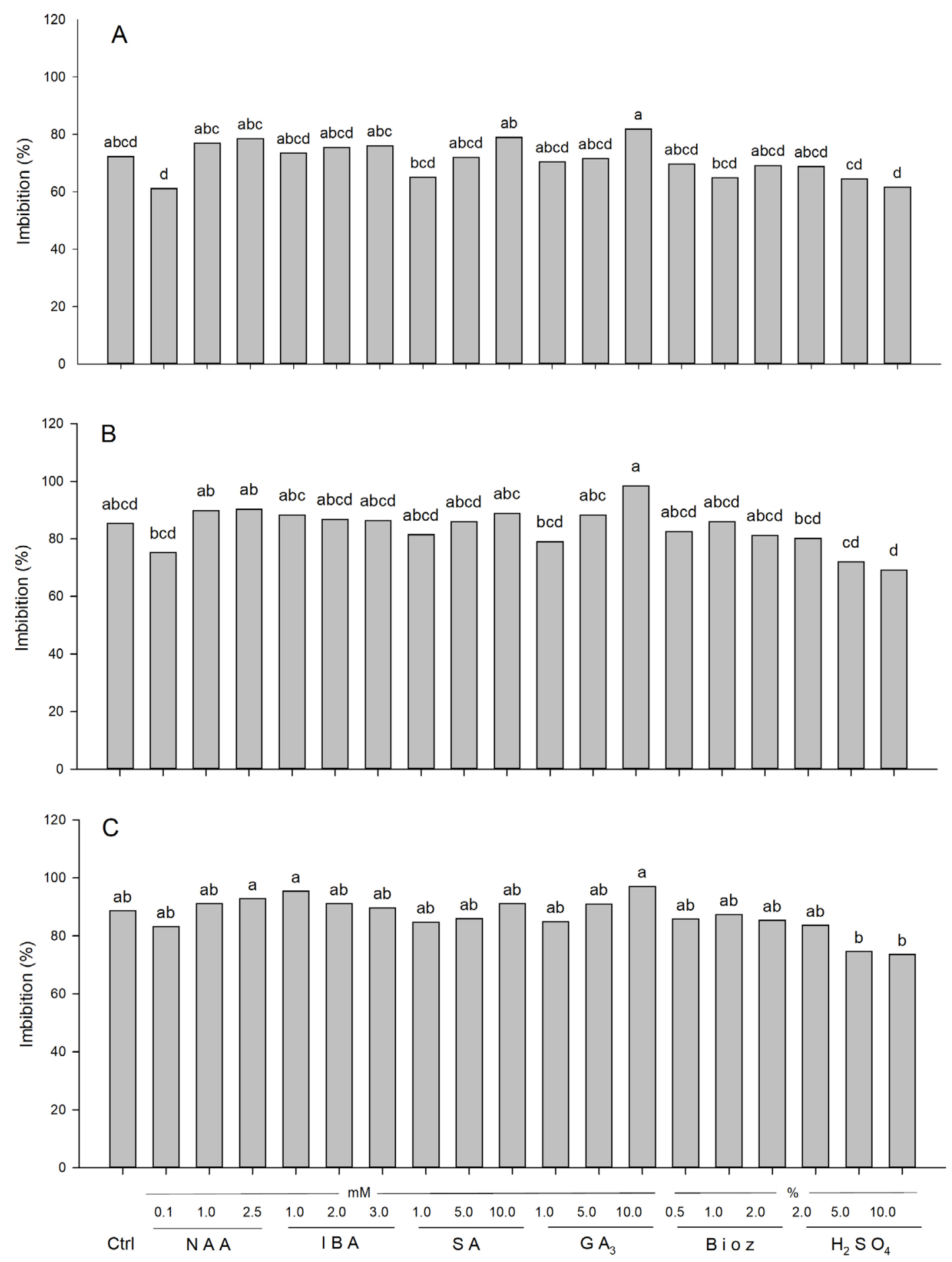

Figure 1: Percent imbibition of piquin pepper seeds in pregermination treatments at $2 \mathrm{~h}(\mathrm{~A}), 24 \mathrm{~h}(\mathrm{~B})$, and $48 \mathrm{~h}$ (C) immersion periods in distilled water (Ctrl), naphthaleneacetic acid (NAA), salicylic acid (SA), gibberellic acid $\left(\mathrm{GA}_{3}\right)$, indolebutyric acid (IBA), Biozyme (Bioz), and sulfuric acid $\left(\mathrm{H}_{2} \mathrm{SO}_{4}\right)$. The values shown in each bar represent the mean $(n=3)$. Different letters indicate statistically significant differences between treatments (Tukey, $p \leq 0.05$ ). 
At $24 \mathrm{~h}$ of imbibition, the weight of the seeds changed from 69.1 to $98.3 \%$, which shows a trend similar to that we observed after $2 \mathrm{~h}$ of imbibition, but at a slightly slower seed hydration rate (Figure 1B). After $48 \mathrm{~h}$, the imbibition increased to between 73 and $97 \%$; however, immersion of seeds in $\mathrm{GA}_{3}(10 \mathrm{mM})$ caused a $1 \%$ decrease in their weight. The imbibition percentages of seeds immersed in $\mathrm{GA}_{3}$, NAA, IBA, Bioz, SA, and $\mathrm{H}_{2} \mathrm{SO}_{4}$ solutions were not significantly different from that in the control, regardless of the imbibition period (Figure 1 A-C).

Several studies have noticed that the seed coat, in addition to protecting the embryo and reserve tissues, also plays a role in the regulation of germination by preventing the entrance of water (Smýkal et al., 2014). Thus, the seed coat represents a physical dormancy mechanism that hampers the germination of seeds of species in the Solanaceae family, including those in the Capsicum genus. Since in all treatments we observed that the imbibition began at $2 \mathrm{~h}$ of immersion, we concluded that the seed coat is not a barrier to imbibition that would cause a physical dormancy of piquin pepper seeds and that dormancy in the piquin pepper seeds must be associated with other factors. The time of imbibition depends on seed characteristics such as the amount of tissue to be hydrated, that is, seed weight and size, initial water content, and water availability (Louf et al., 2018). The same response was observed by similar studies in the Capsicum genus. Espitia-Hernández et al. (2019) evaluated the germination-inhibiting effects of different concentrations of growth regulators and potassium nitrate in chile ancho pepper seeds (Capsicum annuum) and found no significant differences in the treatments relative to the control. Garruña-Hernández et al. (2014) reported a similar absence of significant differences in the imbibition of Habanero pepper (C. chinense Jacq.) seeds after 12, 36, and $60 \mathrm{~h}$ immersion in $\mathrm{ABA}$ and $\mathrm{G}_{3}$ relative to the control. In contrast, Cano-Vázquez et al. (2015) found a $70 \%$ increase in the water content of piquin pepper seeds (collected in Tuxpan, Veracruz) after $8 \mathrm{~h}$ of imbibition. Monroy-Vázquez et al. (2017) also observed that the imbibition of seeds from four species of Opuntia took place during the first hours of immersion.

The rapid imbibition during the first $2 \mathrm{~h}$ of immersion that we observed in piquin pepper seeds, and its continued increase after $48 \mathrm{~h}$, is related to the wild nature of the mother plants; that is, it suggests that the presence of morphophysiological characteristics (such as testa thickness, osmolytes, and osmotic potential) allows seeds to take maximum advantage of the variable episodes of soil water availability from rainfall, therefore improving the germination and generational succession of the species' populations. In a similar context, RodríguezMorales, Guillén and Casas (2013) reported that wild seeds of Stenocereus stellatus in a hydric-stress gradient had higher germination percentages than managed populations.

Imbibition is the initial phase of the germination process; however, dormant seeds may express other factors, such as the synthesis of inhibitors that arrest the subsequent phases of the process (Weitbrecht; Müller; Leubner-Metzger, 2011). Because imbibition is driven by differences in the water potential, inviable seeds might also absorb water (Smýkal et al., 2014), as could have occurred in our $10 \% \mathrm{H}_{2} \mathrm{SO}_{4}$ treatment after $48 \mathrm{~h}$, in which we observed a similar seed weight gain as in the control, but with differences in seed germination percentage (Figure 2C).

\section{Seed germination}

The diverse treatments applied by agronomists for homogenizing the germination response of seeds are aimed at overcoming the problem of uneven germination that limits the establishment of crops. The results from our analysis of variance showed significant differences $(p \leq 0.05)$ in germination response between treatment solutions and immersion times. Treatment with $2 \% \mathrm{Bioz}$ promoted the highest germination response $(79.3 \%)$ regardless of the immersion period (Figure 2). GonzálezCortés et al. (2015) reported a similar response in wild chili pepper seeds collected in the state of Tabasco, Mexico, immersed in $1.6 \%$ Bioz for $24 \mathrm{~h}$, which increased their germination by $40 \%$ relative to the control. The authors of the study attributed this increase in germination response to the influence of the product's chemical content (minerals, $\mathrm{GA}_{3}$, auxin, and cytokines) on the biochemical, metabolic, and physiological processes taking place during seed germination (Carrera-Castaño et al., 2020).

In our study, treatment of piquin pepper seeds with the growth regulators NAA and IBA improved their germination. The germination percentage of seeds immersed for $2 \mathrm{~h}$ in $1.0 \mathrm{mM}$ NAA was $62 \%$, and it was $54.6 \%$ after $24 \mathrm{~h}$ in $0.1 \mathrm{mM} \mathrm{NAA}$; after $48 \mathrm{~h}$ in 0.1 and 1.0 mM NAA, it was 37 and $42 \%$, respectively. These results agree with those of Quintana et al. (2013), who treated seeds of Clitoria ternatea L. conserved for 20 years in a seed bank with NAA, $\mathrm{AG}_{3}$, and $\mathrm{NAA}+\mathrm{AG}_{3}$, finding an $18 \%$ germination percentage increase with $0.5 \mu \mathrm{M}$ NAA relative to the control. 

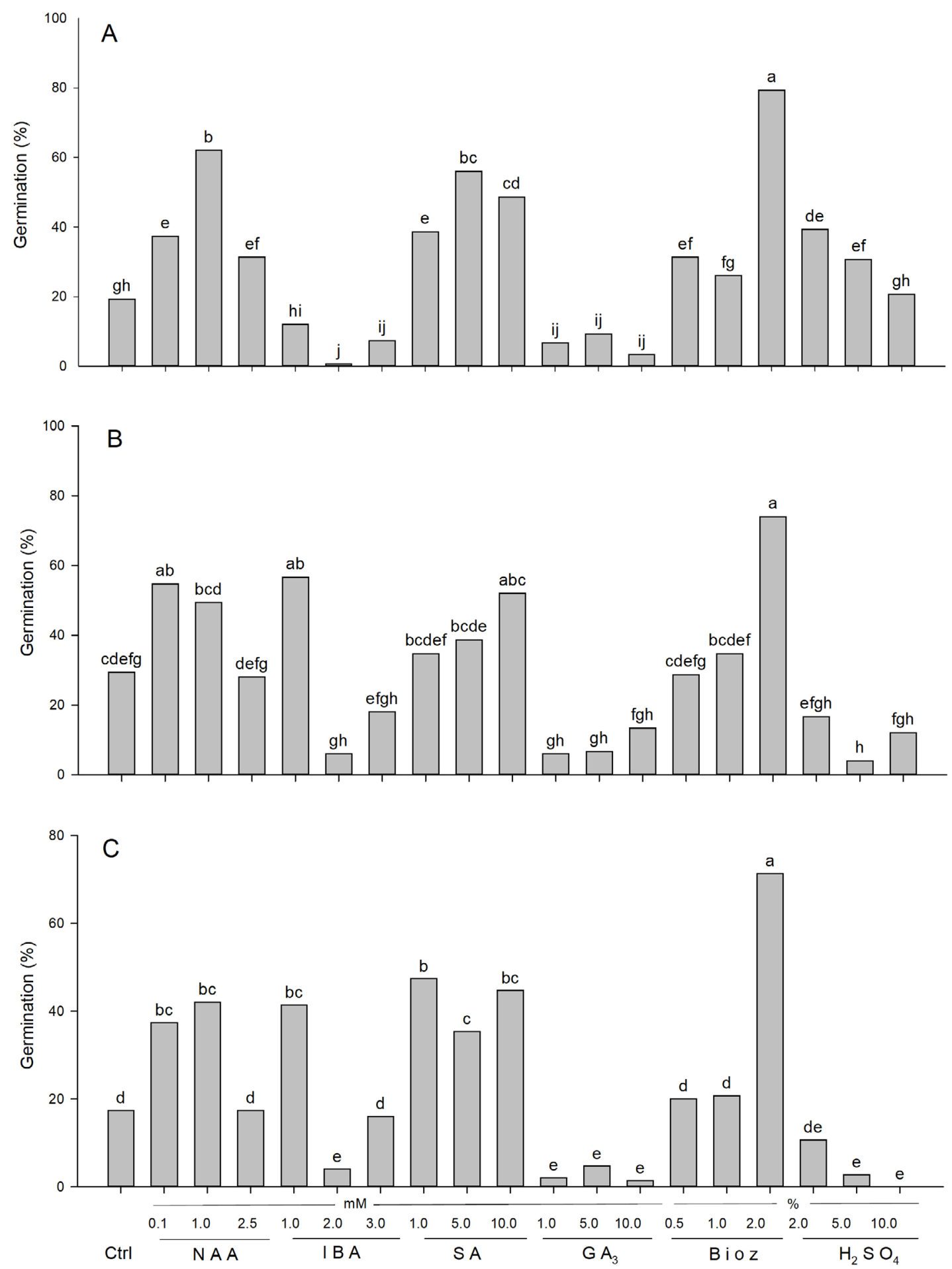

Figure 2: Percent germination of piquin pepper seeds in pregermination treatments at $2 \mathrm{~h}(\mathrm{~A}), 24 \mathrm{~h}(\mathrm{~B})$, and 48 h (C) immersion periods in distilled water (Ctrl), naphthaleneacetic acid (NAA), salicylic acid (SA), gibberellic acid $\left(\mathrm{GA}_{3}\right)$, indolebutyric acid (IBA), Biozyme (Bioz), and sulfuric acid $\left(\mathrm{H}_{2} \mathrm{SO}_{4}\right)$. The values shown in each bar represent the mean $(n=3)$. Different letters indicate statistically significant differences between treatments (Tukey, $p \leq 0.05$ ). 
We observed that immersion in $1.0 \mathrm{mM}$ IBA produced the highest germination percentages after $24 \mathrm{~h}$ (56.6\%) and $48 \mathrm{~h}(41.3 \%)$ (Figure 2). The treatment with higher concentrations of IBA produced lower germination percentages than the control at all immersion periods. Similarly, in a study with Passiflora quadrangularis L. seeds, Carranza et al. (2016) obtained a 3\% increase in germination after 13 days when treating seeds with 1-2.95 mM IBA relative to the control treatment. Guangwu and Xuwen (2014) evaluated the germination response of two varieties of Pinus massoniana Lamb. (Dai 1 and Dai 2) treated with IAA and $\mathrm{GA}_{3}$, finding increased germination in both treatments; however, the increase with IAA depended on the variety (33\% in Dai 1 and $27 \%$ in Dai 2 ), which suggests the involvement of IAA and $\mathrm{GA}_{3}$ in the feedback mechanisms regulating seed germination.

Immersion in $\mathrm{GA}_{3}$, at all the concentrations and immersion periods we tested, did not improve the germination of piquin pepper seeds, although treatment with $10 \mathrm{mM} \mathrm{GA}_{3}$ for $24 \mathrm{~h}$ resulted in a slight tendency to improve it. Our results in this regard differ from those of Prado-Urbina et al. (2015), who reported a 30 to $40 \%$ increase in the germination of wild accessions of $C$. annuum seeds from Tabasco when the seeds were previously immersed in $14.43 \mathrm{mM} \mathrm{GA}_{3}$. Similarly, after treatment with $0.577 \mathrm{mM} \mathrm{GA}_{3}$, Quintero et al. (2018) observed a $70 \%$ increase in the germination of piquin pepper seeds collected in Tamaulipas and San Luis Potosí, Mexico. We know that the essential function of gibberellins in germination is mediated by their equilibrium with abscisic acid (Miransari; Smith, 2014; Hu et al., 2021) and that gibberellins contribute to overcoming dormancy and nourishing the embryo through the activity of the hydrolytic enzyme $\alpha$-amylase. Therefore, because imbibition was not the limiting factor (Figure 1), it is possible that the low germination percentages that we observed in treatments with $\mathrm{GA}_{3}$ might have been due to the hormone's effect on $\alpha$-amylase at the concentrations and immersion periods that we assayed. Other endogenous factors known to control germination are plant hormone activities, seed provenance, present population variation, and seed viability (Cano-Vázquez et al., 2015).

The imbibition of seeds with SA had effects on their germination under all treatment conditions. The highest germination percentage that we observed was $56 \%$, when seeds were immersed in $5 \mathrm{mM}$ SA for $2 \mathrm{~h}$, while at $1.0 \mathrm{mM}$ for $24 \mathrm{~h}$, it was $47.3 \%$. The differences between seeds immersed in SA for $24 \mathrm{~h}$ and the control were not statistically significant (Figure 2). Ahmed et al. (2020) had similar germination improvement results with sweet pepper cv. Yolo seeds immersed in SA $(0.2$ and $0.3 \mathrm{mM})$, $33 \%$ of which germinated. SA is a plant hormone involved in growth regulation and plant development that also is associated with tolerance to several biotic and abiotic stress factors and seed germination (Liu et al., 2019). The induction of malate dehydrogenase activity by SA is involved in the germination of Arabidopsis thaliana (L.) Heynh. and other plants, with high levels of the enzyme correlating with the beginning of germination (Weitbrecht et al., 2011). Stress from $\mathrm{NaCl}$ during the germination of Limonium bicolor (Binge) Kuntz seeds is modulated by SA through the stimulation of endogenous $\mathrm{GA}_{3}$ and $\alpha$-amilasa and the inhibition of ABA (Liu et al., 2019). The metabolic complexity of the seed germination process is made evident by the communication between biosynthetic pathways (Weitbrecht et al., 2011).

The imbibition of seeds in $2 \% \mathrm{H}_{2} \mathrm{SO}_{4}$ for $2 \mathrm{~h}$ increased their germination by $103 \%$, but after $2 \mathrm{~h}$ of immersion at all concentrations, germination was reduced by $85 \%$ relative to the control (Figure $2 \mathrm{~A}$ ). $\mathrm{H}_{2} \mathrm{SO}_{4}$ is one of the acids most commonly used for the scarification of seeds to allow their imbibition. The decrease in germination percentage that we observed might have been due to cellular damage caused by prolonged immersion in the acid. Thus, the selection of chemical seed scarification treatments must consider the species, concentration, and immersion time. In that regard, Merino-Valdés et al. (2018) observed the destruction of Capsicum pubescens Ruiz \& Pav. seeds immersed for $30 \mathrm{~min}$ in 100,75 , and $65 \% \mathrm{H}_{2} \mathrm{SO}_{4}$ solutions.

\section{Time to obtain $50 \%$ germination $\left(\mathrm{T}_{50}\right)$}

The time to obtain $50 \%$ germination $\left(\mathrm{T}_{50}\right)$ was statistically different $(\mathrm{p} \leq 0.05)$ among the immersion treatments (Figure 3), and it was reached between 10 and 20 days. In the first $2 \mathrm{~h}$ of imbibition in NAA $(0.1 \mathrm{mM})$, $\mathrm{SA}(10 \mathrm{mM}), \mathrm{GA}_{3}(5$ and $10 \mathrm{mM}), \mathrm{Bioz}(1.0 \%)$, and $\mathrm{H}_{2} \mathrm{SO}_{4}$ $(5 \%)$, the $\mathrm{T}_{50}$ values were longer than $20 \mathrm{~d}(22.2,22.3,25.1$, $26.3,25.2$, and $22.2 \mathrm{~d}$, respectively). Seed immersion for $24 \mathrm{~h}$ in $10 \mathrm{mM} \mathrm{GA}_{3}$ and for $48 \mathrm{~h}$ in $1.0 \mathrm{mM} \mathrm{GA}_{3}$ were the only treatments in which $\mathrm{T}_{50}$ was above 20 (22.75 and 27.5 $\mathrm{d}$, respectively). The remaining treatments did not show significant differences relative to the control. The lowest $\mathrm{T}_{50}$ value that we recorded, which correlated with a higher germination percentage, was that for $2 \%$ Bioz (79.3\% germination and $11 \mathrm{~d} \mathrm{~T}_{50}$ ), followed by $1.0 \mathrm{mM} \mathrm{NAA}$ $(62.0 \%, 14 \mathrm{~d})$ and $5 \mathrm{mM} \mathrm{SA}(56.0 \%, 15 \mathrm{~d})$. The reduction in the $\mathrm{T}_{50}$ value that we observed could have been due to treatments causing the rapid and irreversible initiation of the metabolic processes associated with germination once seeds are imbibed (Louf et al., 2018). 

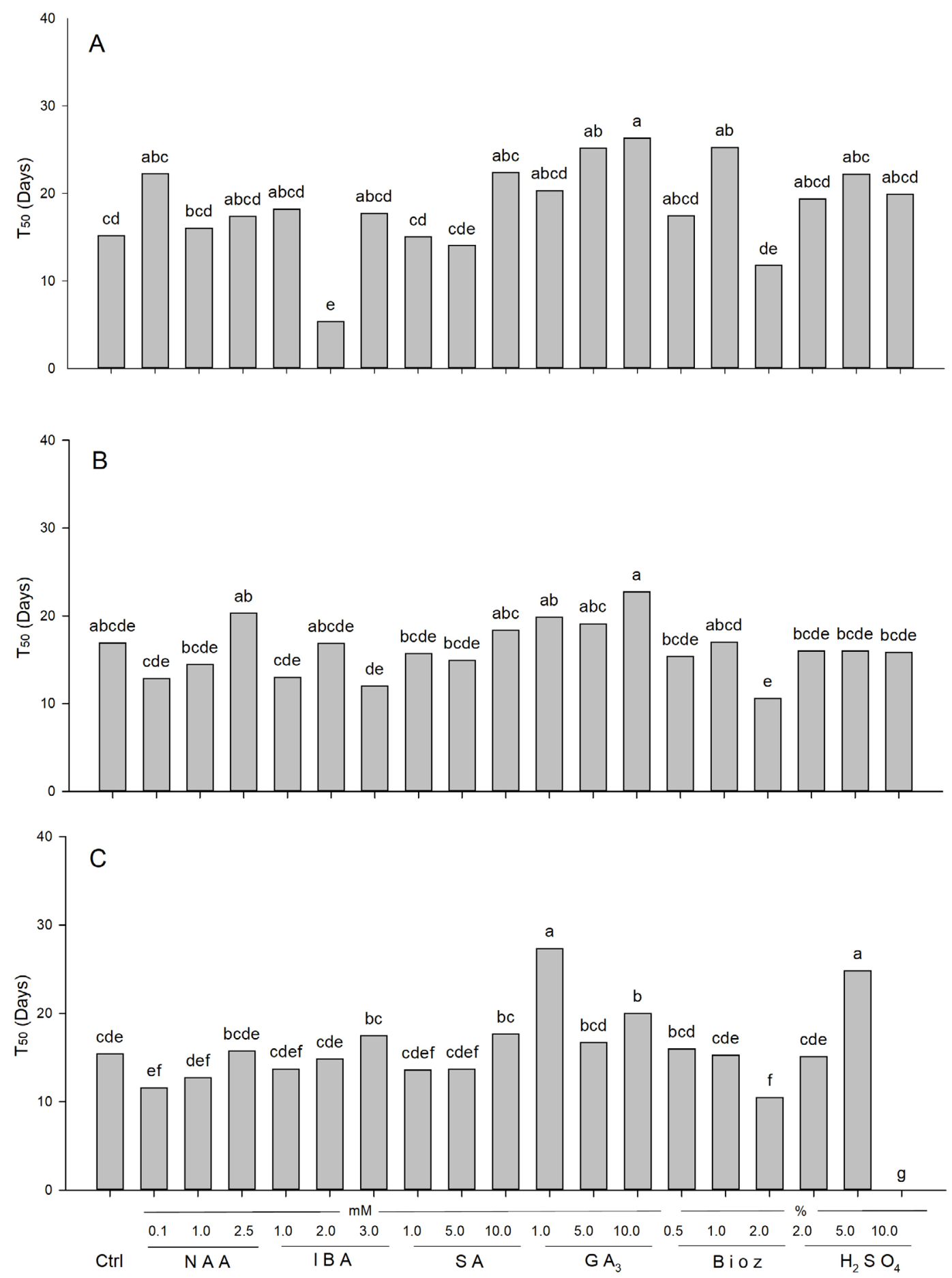

Figure 3: Time in days to obtain $50 \%$ germination $\left(T_{50}\right)$ of piquin pepper seeds in pregermination treatments at 2 $\mathrm{h}(\mathrm{A}), 24 \mathrm{~h}(\mathrm{~B})$, and $48 \mathrm{~h}(\mathrm{C})$ immersion periods in distilled water (Ctrl), naphthaleneacetic acid (NAA), salicylic acid $(\mathrm{SA})$, gibberellic acid $\left(\mathrm{GA}_{3}\right)$, indolebutyric acid (IBA), Biozyme (Bioz), and sulfuric acid $\left(\mathrm{H}_{2} \mathrm{SO}_{4}\right)$. The values shown in each bar represent the mean $(n=3)$. Different letters indicate statistically significant differences between treatments (Tukey, $p \leq 0.05$ ). 
Variations in $\mathrm{T}_{50}$ can be caused by treatments and seed provenance (ecotype), as reported for piquin pepper seeds collected in northwestern Mexico by López-España et al. (2017), who observed a $T_{50}$ of $26.39 \mathrm{~d}$ under variable temperature and of $57.7 \mathrm{~d}$ at constant temperature (the authors found the lowest $\mathrm{T}_{50}$ when sunlight was reduced by $50 \%$ ), and by Quintero et al. (2018), who recorded a $\mathrm{T}_{50}$ of $8.1 \mathrm{~d}$, representing a reduction of $16 \mathrm{~d}$ relative to the control, with a treatment combining $\mathrm{KNO}_{3}$ and $\mathrm{GA}_{3}$.

\section{Coefficient of variation of germination time (CVt)}

The CVt values we found did not show statistically significant differences among treatments relative to the control, except for $2 \mathrm{mM}$ IBA, 1 and $10 \mathrm{mM} \mathrm{GA}_{3}$, and $10 \% \mathrm{H}_{2} \mathrm{SO}_{4}$, in which the $\mathrm{CVt}$ values were less than 2. These low CVt values were due to the limited germination occurring during a short period. The highest
CVt (39.6) and germination values (79.2\%) and the lowest $\mathrm{T}_{50}$ value (11 d) that we observed corresponded to the seeds treated with $2 \%$ Bioz, followed by NAA and SA (Figure 4).

The variability in germination response that we observed in the piquin pepper seeds might have ecological, genetic, and metabolic causes. According to Mendes-Rodrigues, Oliveira and Ranal (2011), the asynchrony and heterogeneity of germination responses in seeds of wild plant species increase their capability to survive. Thus, the strategy followed by wild plant species such as piquin pepper is to disperse seeds with different degrees of dormancy to reduce the risk of germination in an unfavorable environment, while the mechanisms of dormancy interruption involve environmental factors, the plant's genetic profile, and the endogenous levels of hormonal activity (Smýkal et al., 2014; Carrera-Castaño et al., 2020).

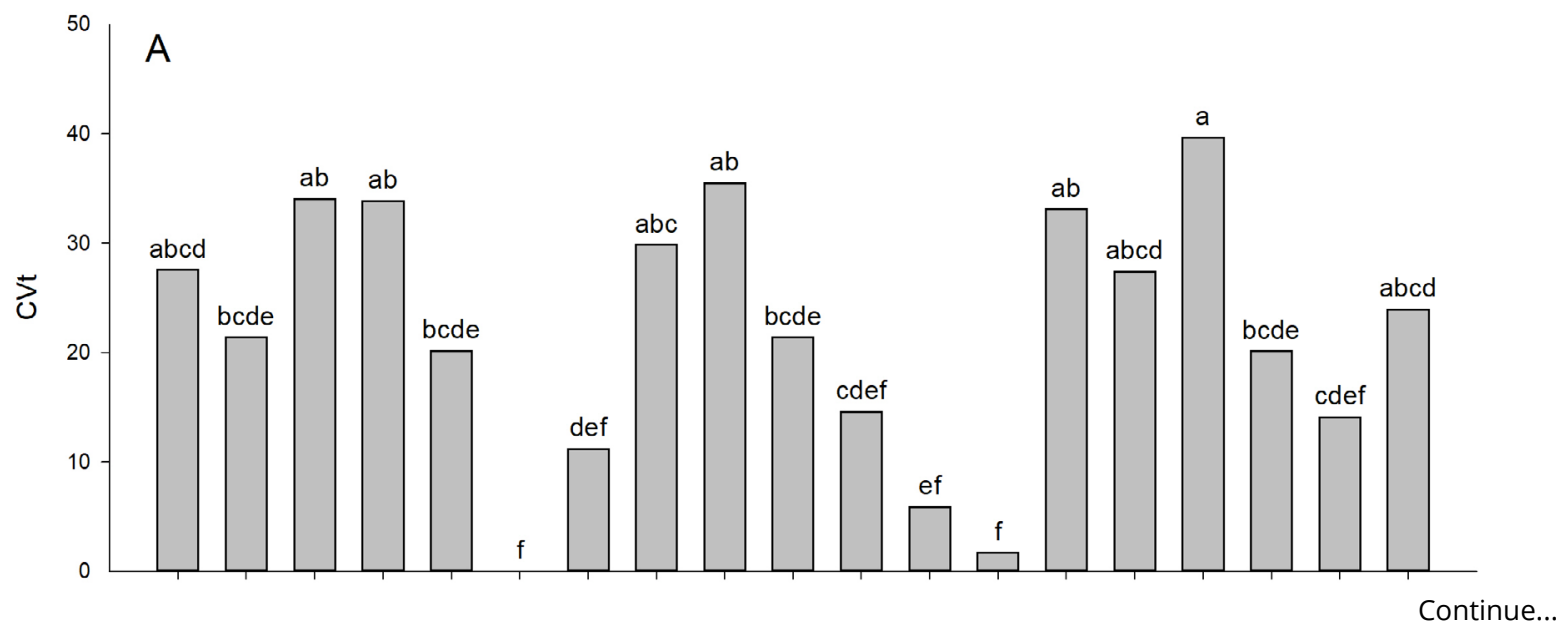

Figure 4: Coefficient of variation of germination time (CVt) of piquin pepper seeds in pregermination treatments

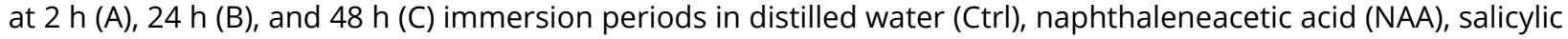
acid (SA), gibberellic acid $\left(\mathrm{GA}_{3}\right)$, indolebutyric acid (IBA), Biozyme (Bioz), and sulfuric acid $\left(\mathrm{H}_{2} \mathrm{SO}_{4}\right)$. The values shown in each bar represent the mean $(n=3)$. Different letters indicate statistically significant differences between treatments (Tukey, $p \leq 0.05$ ). 

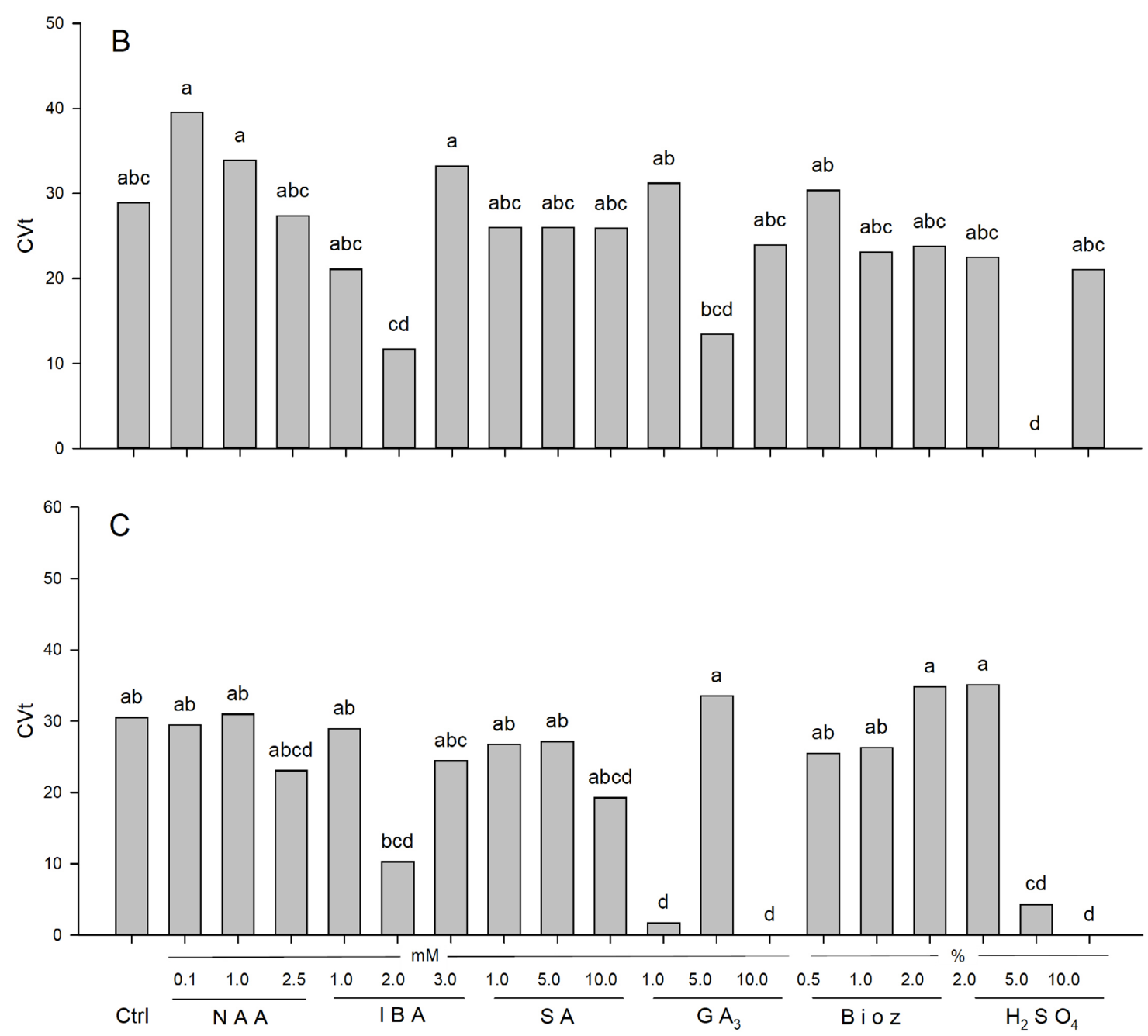

Figure 4: Continuation.

\section{CONCLUSIONS}

According to our results, we concluded that the pregermination treatments we assayed improved the physiological potential for the germination of piquin pepper seeds by modifying $\mathrm{T}_{50}$ and $\mathrm{CVt}$. Because water imbibition was high during the first hours of immersion, we demonstrated that piquin pepper seeds lack physical dormancy. Among the pregermination treatments that we applied, the best response occurred after imbibition in 2\% Bioz for $2 \mathrm{~h}$, followed by those in treatments with $1 \mathrm{mM} \mathrm{NAA}$ and $5 \mathrm{mM} \mathrm{SA}$.

\section{AUTHOR CONTRIBUTIONS}

Conceptual idea: Poot-Poot, W.A.; Methodology design: Poot-Poot, W.A.; Cano-González, M.A.; Ayi-
Gutiérrez, B.A.; Data collection: Cano-González, M.A.; Osorio-Hernández, E.; Ayi-Gutiérrez, B.A.; Data analysis and interpretation: Rangel-Lucio, J.A.; Delgado-Martínez, R.; Poot-Poot, W.A.; and Writing and editing: CanoGonzález, M.A.; Osorio-Hernández, E.; Poot-Poot, W.A.; Rangel-Lucio, J.A.

\section{ACKNOWLEDGMENTS}

The main author acknowledges the Consejo Nacional de Ciencia y Tecnología (CONACYT) for granting his doctoral scholarship (No. 749126) and the Faculty of Engineering and Sciences of the Autonomous University of Tamaulipas (UAT) for providing their facilities during this research. 


\section{REFERENCES}

AHMED, W. et al. Role of salicylic acid in regulating ethylene and physiological characteristics for alleviating salinity stress on germination, growth and yield of sweet pepper. PeerJ, 8:e8475, 2020.

BARCHENGER, D. W.; BOSLAND, P. W. Exogenous applications of capsaicin inhibits seed germination of Capsicum annuum. Scientia Horticulturae, 203:29-31, 2016.

CANO-VÁZQUEZ, A. et al. Variación en grados de latencia en semillas entre colectas de chile piquín (Capsicum annuum var. glabriusculum). Botanical Sciences, 93(1):175-184, 2015.

CARRANZA, C. et al. Efecto de la aplicación de reguladores de crecimiento sobre la germinación de semillas de badea (Passiflora quadrangularis L.) en condiciones de invernadero. Revista Colombiana de Ciencias Hortícolas, 10(2):284-291, 2016.

CARRERA-CASTAÑO, G. et al. An updated overview on the regulation of seed germination. Plants, 9(6):703, 2020.

CARVALHO, M. P.; SANTANA, D. G.; RANAL, M. A. Emergência de plântulas de Anacardium humile A. St.-Hil. (Anacardiaceae) avaliada por meio de amostras pequenas. Brazilian Journal of Botany, 28(3):627-633, 2005.

COOLBEAR, P.; FRANCIS, A.; GRIERSON, D. The effect of low temperature pre-sowing treatment on the germination performance and membrane integrity of artificially aged tomato seeds. Journal of Experimental Botany, 35(11):16091617, 1984.

ESPITIA-HERNÁNDEZ, P. et al. Respuesta fisiológica de semillas de chile ancho (Capsicum annuum L.) a reguladores de crecimiento. Revista Mexicana de Ciencias Agrícolas, 10(4):829-837, 2019.

FAROOQ, M. et al. Thermal hardening: A new seed vigor enhancement tool in rice. Journal of Integrative Plant Biology, 47(2):187-193, 2005.

GARRUÑA-HERNÁNDEZ, R. et al. Acondicionamiento presiembra: Una opción para incrementar la germinación de semillas de chile habanero (Capsicum chinense Jacq.). Agrociencia, 48(4):413-423, 2014.

GONZÁLEZ-CORTÉS, N. et al. Germinación del Chile amashito (Capsicum annuum L. var. Glabriusculum) en el sureste mexicano. Revista Mexicana de Ciencias Agrícolas, 6(SPE11):2211-2218, 2015.
GUANGWU, Z.; XUWEN, J. Roles of gibberellin and auxin in promoting seed germination and seedling vigor in Pinus massoniana. Forest Science, 60(2):367-373, 2014.

HAYANO-KANASHIRO, C.; GÁMEZ-MESA, N.; MEDINA-JUÁREZ, L. A. Wild pepper Capsicum annuum L. var. glabriusculum: Taxonomy, plant morphology, distribution, genetic diversity, genome sequencing, and phytochemical compounds. Crop Science, 56(1):1-11, 2016.

HERRERA-AGUILAR, A. et al. Deterioration of the quality of the piquín pepper seed from four collections in Querétaro and Guanajuato. Revista Mexicana de Ciencias Agrícolas, 9(8):1627-1638, 2018.

HU, Y. et al. The heading-date gene Ghd7 inhibits seed germination by modulating the balance between abscisic acid and gibberellins. The Crop Journal, 9:297304, 2021.

LIN, T. H. et al. Growing environment and heat treatment effects on intra-and interspecific pollination in chile pepper (Capsicum spp.). Agronomy, 11:1275, 2021.

LIU, J. et al. Exogenous salicylic acid improves the germination of Limonium bicolor seeds under salt stress. Plant Signaling and Behavior, 14(10):e1644595, 2019.

LÓPEZ-ESPAÑA, R. G. et al. Effects of temperature wild chili pepper (Capsicum annuum var. glabriusculum) germination grown under two light conditions. Acta Agronómica, 66(1):69-74, 2017.

LOUF, J. F. et al. Imbibition in plant seeds. Physical Review E, 98(4):1-5, 2018.

MARES-QUIÑONES, M. D.; VALIENTE-BANUET, J. I. Horticultural aspects for the cultivated production of piquin peppers (Capsicum annuum L. var. glabriusculum) a review. HortScience, 54(1):70-75, 2019.

MEDINA-MARTÍNEZ, T. et al. Avances y perspectivas de investigación del chile piquín en Tamaulipas, México. CienciaUAT, 4(4):16-21, 2010.

MENDES-RODRIGUES, C.; OLIVEIRA, P. E.; RANAL, M. A. Seed germination and seedling growth of two Pseudobombax species (Malvaceae) with contrasting habitats from Brazilian Cerrado. Revista de Biología Tropical, 59(4):19151925, 2011.

MERINO-VALDÉS, M. et al. Influencia de tratamientos pregerminativos en semillas de chile manzano (Capsicum pubescens Ruiz and Pav.). Acta Agronómica, 67(4):531-537, 2018. 
MIRANSARI, M.; SMITH, D. L. Plant hormones and seed germination. Environmental and Experimental Botany, 99:110-121, 2014.

MIRELES-RODRÍGUEZ, E. et al. Preacondicionamiento en la germinación de cuatro colectas de chile piquín (Capsicum annuum var. aviculare) de Tamaulipas, México. Acta Agrícola y Pecuaria, 1(3):99-106, 2015.

MONROY-VÁZQUEZ, M. E. et al. Imbibición, viabilidad y vigor de semillas de cuatro especies de Opuntia con grado distinto de domesticación. Agrociencia, 51(1):27-42, 2017.

PRADO-URBINA, G. et al. Germinación de semillas de chiles silvestres en respuesta a tratamientos pre-germinativos. Ecosistemas y Recursos Agropecuarios, 2(5):139-149, 2015.

QUINTANA, M. et al. Efecto de dos reguladores de crecimiento y condiciones de iluminación en la germinación de semillas conservadas de Clitoria ternatea. Biotecnología Vegetal, 13(2):113-119, 2013.

QUINTERO, C. M. F. et al. Relieving dormancy and improving germination of Piquín chili pepper (Capsicum annuum var. glabriusculum) by priming techniques. Cogent Food and Agriculture, 4(1):1550275, 2018.

RODRÍGUEZ-MORALES, J.; GUILLÉN, S.; CASAS, A. Consecuencias de la domesticación de Stenocereus stellatus en el tamaño de las semillas y en la germinación en un gradiente de estrés hídrico. Botanical Sciences, 91(4):485-492, 2013.
SILVA, A. C. D. et al. Osmotic treatment, growth regulator and rooter in Tabebuia roseoalba (RIDL.) sandwith seeds for direct sowing. Journal of Seed Science, 42:e202042022, 2020.

SMÝKAL, P. et al. The role of the testa during development and in establishment of dormancy of the legume seed. Frontiers in Plant Science, 5:1-19, 2014.

TRETO-ALEMÁN, K. M. et al. Enrichment of edible oil by phenolic and antioxidant compounds of piquín chili (Capsicum annuum var. glabriusculum). CienciaUAT, 15(2):156-168, 2021.

TERSKIKH, V. et al. In vivo ${ }^{1} \mathrm{H}-\mathrm{NMR}$ microimaging during seed imbibition, germination, and early growth. Methods in Molecular Biology, 773:319-327, 2011.

VILLALON-MENDOZA, H. et al. Factors influencing the price of chile piquin wild chili (Capsicum annuum L. var. glabriusculum) of North-east Mexico. International Journal of Bio-resource and Stress Management, 5(1):128-131, 2014.

WATKINS, J. T.; CANTLIFFE, D. J. Hormonal control of pepper seed germination. Hortscience, 18(3):342343, 1983.

WEITBRECHT, K.; MÜLLER, K.; LEUBNER-METZGER, G. First off the mark: Early seed germination. Journal of Experimental Botany, 62(10):3289-3309, 2011. 